constants of Nature lose their quality of constancy, and must change continually with the time. Milne was led to the same conclusion by a very different road; he reached it from a study of his cosmological principle. By whatever road we arrive, we come into a fantastic new world.

We may avoid the need for a continual creation of matter by supposing that the natural physical unit of time changes pari passu with the age of the universe. Then the measure of the age of the universe stays always the same, as does also the number of particles in the universe. But we now find that either the mass or the charge of an electron must continually change.

All this seems strange to old-fashioned physics, but it simplifies some things and removes some difficulties. When, for example, we study the spectrum of a nebula at 250 million light-years distance, we are in effect watching the emission of light from the atoms of 250 million years ago. We find that the spectral lines all show a displacement to the red, its amount being strictly proportional to the age of the light. The simplest interpretation of what we see is that the atoms of those earlier days were not the same as the atoms of to-day. Atoms seem to have given out radiation of longer wave-length than they do now, and so were apparently larger-or perhaps their electrons moved more slowly in their orbits and so took longer to complete their revolutions, possibly because the electric attraction on them was less intense. There are many possibilities, each with its merits, but also with many demerits.

Whatever the final solution of this vast problem may prove to be, it is already clear that there is no solution on the lines of the kind of dynamics that we learned at school. The mechanical interpretation of the universe fails as completely in the large-scale world of astronomy as it has already failed in the small-scale world of atomic physics. The quantum theory has replaced mechanics in the physical world; we still do not know what is destined to replace it in the world of astronomy.

\section{CULTIVATION OF THE DOUGLAS FIR IN GREAT BRITAIN}

\section{BY ALEXANDER L. HOWARD}

$\mathrm{T}$ $\mathrm{HE}$ question of reconstruction after the War is uppermost in many thinking minds to-day, and reafforestation should be given an important place on the programme.

Until the year 1914 a period of nearly a hundred years elapsed, during which time in Great Britain only desultory planting of little importance was carried out. The War of 1914-18 came, bringing with it a merciless but unavoidable devastation of our forests, and subsequent efforts proved wholly inadequate to restore our position. If the situation was serious then, it is desperate now, as the huge demand for timber which has arisen since the outbreak of war in 1939 has dealt another crippling blow to the woodlands of Britain. It is easy to see how this grave situation has come about. In the years 1937 and 1938 (1939 was not a complete year) we imported from the U.S.S.R., Finland, Sweden, Poland, Norway and elsewhere (including Canada and America) the following :
1937
Softwoods
$11,732,000$ loads
Money value (sterling)
$8,660,000$
$£ 51,574,000$

So as to make the immensity of this problem clearer to those who are less acquainted with the matter :

The quantity imported in 1937 would weigh approximately, of our class of timber

The transport of which would employ

(each with an average capacity of 6 tons,

but which in practice generally would average, for timber, only half the quantity
named.)

If the full 6 tons were carried, this would

require of the average carrying capacity of

timber over the railways of Britain 133,400 goods trains.

These immense shipments were suddenly and completely cut off, and we were obliged to rely on those supplies which could still be obtained from Canada, the United States, and our own home-grown forests. The largest contribution, which has consisted of Douglas fir, has so far been provided by Canada, and perhaps admittedly or unknowingly by the United States.

The Douglas fir, which flourishes in the north-west coast of North America, is remarkable for its height and size, its rapid growth, and the amazing extent of its usefulness.

According to Pliny, when Xerxes first saw the plane tree (Platanus orientalis) in southern Europe, he halted his entire army of 170,000 soldiers to admire the "pulchritude and procerity" of one single tree. Well might he have done so when he beheld for the first time the majestic height and wonderfully straight bole of the Douglas fir. Although, however, in places other than its natural habitat its lower branches grow in a graceful sweep, for sheer beauty it cannot be considered a competitor with the plane.

Gibson, speaking of the Douglas fir, wrote: "The largest are 300 feet high, occasionally more, and from 8 to 10 feet in diameter. The average among the Rocky Mountains is from 80 to 100 feet high and 2 to 4 feet in diameter. The amount of timber yielded by one tree may be realised from the experience of Dr. Watney (of 'Buckholt', Pangbourne), who was present at the felling of one in Washington Territory, U.S.A. The height of the trunk was 250 feet and that to the lowest bough was 157 feet. The following were the diameters at different heights above the ground :

" 83 inches at 7 feet, 65 inches at 37 feet, 52 inches at 107 feet, and 32 at 191 feet.

"The trunk was sawn off at a height of 7 feet above the ground (where it showed 420 annual rings), and 184 feet of its length yielded 21,503 feet converted, equalling 1,958 feet cube. It took nine railway trucks to convey the timber from London to Pangbourne. The timber contained practically no sap, very few shakes, but some of the planks contained dead knots. Large sections of the trunks (exceeding 7 feet in diameter) are familiar in England to those who visit Kew Gardens, and the Natural History Museum, South Kensington. The Douglas fir flagstaff formerly at Kew Gardens, which was presented by the Government of British Columbia in 1861, was well known. It was 159 feet in length, and measured 1 foot 8 inches in diameter at the base, and 5 inches in diameter at the small end. This is now surpassed by the flagstaff which was erected in 1919 and, like the former one, it was presented by the Government of British Columbia."

The present flagstaff at Kew towers to a height of $214 \mathrm{ft}$., half as high again as the Nelson Monument 
-measuring more than a foot in diameter at the top, and about $3 \mathrm{ft}$. in diameter at the base. If we accept reports which date back many years, a record height of more than $400 \mathrm{ft}$. has been claimed for these trees. Such a tree would top the cross on St. Paul's Cathedral by $35 \mathrm{ft}$.

It would be impossible to overrate the importance of this wood in the exceptional and unexpected demand created by the present War, the figures of production of which amaze and frighten the imagination. When we reflect upon the steady and overwhelming destruction of the timber resources of the world, and the requirements of future generations, we almost wonder how civilization can survive.

Hitherto insufficient efforts have been made to establish Douglas fir trees (Pseudotsuga Douglasii and Ps. taxifolia) in large quantities in Great Britain. The tree was introduced by William Douglas in 1827 , but although occasional efforts were made to plant on a large scale, their prominence and successful production to-day is largely due to proprietors such as the owners of Lythe Hill, Surrey, Murthly Castle, Taymount, Scotland, and Powerscourt, Ireland. Although in some areas success has been achieved, it is only during the last fifty years that attempts have been made to plant this tree for its useful qualities. While it does not thrive in some situations and on certain soils, we have evidence of the marvellous growth to which it can attain in a very short period. About seventy years ago a considerable area was planted with Douglas fir at Lythe Hill by Mr. Bicknell, then forester to the owner. On this same estate many other Douglas firs, in their rather tragic and shortened lifetime, reached a height of 100 feet and more. On the crest of the hill, and placed in such a position that it commanded a view of the whole forest, was an immense tree, known to those who frequented the site as "the monarch tree". It was also one of those planted by Mr. Bicknell about seventy years ago, an unusual specimen of white spruce (Abies sp., possibly grandis). It is not often that a man can plant a tree and during his lifetime actually see it reach a height of about $125 \mathrm{ft}$., with a straight bole moderately clear of branches to a length of $66 \mathrm{ft}$., with three leaders, bringing the full length of the bole to about $100 \mathrm{ft}$., and yet $\mathrm{Mr}$. Bicknell had this satisfaction before he died in 1941 . In all its glory the tree has unfortunately been felled. It contains $544 \mathrm{cub}$. ft. of useful timber, and as growing must have weighed about twenty tons.

It is worthy of notice that the original planter must have been actuated by a diligence and enthusiasm unknown since the time of John Evelyn, as there flourishes on the estate, side by side with the Douglas firs, a great number of unusual American trees, including Sequoia sempervirens, Wellingtonia gigantia, at least two sorts of maple, many Thuya, Cupressus, hemlock, juniper, Cryptomeria japonica, etc. The Sequoia also would seem to have found conditions favourable to its growth, since it has reached a great height and girth.

A magnificent Douglas fir can be seen at Powerscourt, Co. Wicklow, Ireland, planted by the present Viscount's father between 1865 and 1870 . This tree measures to-day $130 \mathrm{ft}$. in height, with a girth of $14 \mathrm{ft} .10 \mathrm{in}$. at breast height-equal to a diameter of nearly $5 \mathrm{ft}$. It is interesting to note that this same tree is mentioned by Henry John Elwes in "Trees of Great Britain and Ireland", when the measurement taken by him in 1904 was recorded as $100 \mathrm{ft}$. in height, $9 \frac{1}{2} \mathrm{ft}$. in girth, with a diameter of $37 \mathrm{in}$.
Other examples of exceptional growth can be seen at Puck Pits in the New Forest, the magnificent avenue at Murthly Castle, and those at Taymount. When it is realized that such trees can be produced in about seventy years, the planting of Douglas firs should be widely encouraged.

A careful inquiry as to the commercial value to-day of an average tree of 70-80 years growth displays the following :

$$
\begin{aligned}
& \begin{array}{cccccc}
\text { Scots pine } & & & & & \text { Per tree } \\
\text { (1) } & \text { My Report } & \ldots & \ldots & \ldots & 278.0 d .
\end{array} \\
& \text { (2) Forestry Commission Report .. 208. 0d. } \\
& \text { Larch } \\
& \text { (1) My Report } \quad \text {. } \quad \ldots \quad \text {. } 37 s .6 d \text {. } \\
& \text { (2) Forestry Commission Report .. 33s. } 0 d \text {. }
\end{aligned}
$$

Average of the Douglas Ar at Haslemere

$$
\text { more than } £ 60 \text { s. }
$$

Henry John Elwes, than whom there was never a more zealous planter, did not display his usual enthusiasm on the subject of Douglas fir, but it is probable that he was influenced by the result of experiments in Scotland and in the cold hills of Gloucestershire, and also because the conditions forty-two years ago were so different from those which obtain to-day.

Experiments have shown, as previously pointed out, that this particular tree can only be successfully reared in certain areas and soils, and under more scientific planting than has been practised heretofore-a handicap always unavoidable with the introduction of a tree the natural habitat of which belongs to a different country and climate.

A large quantity of cones are being collected from the Haslemere trees, which are producing good seed at a crucial moment, since the crop of Canadian seed is reported to have failed.

The vital importance of a sufficient reserve of timber supplies has been peculiarly forced upon us by a demand such as has never before been experienced in the history of Great Britain. Our woodlands, once our pride and glory, are being denuded, not only of their beauty, but also of their value, and it is therefore a national duty, incumbent upon every one of us, without delay, to pursue those measures necessary to repair the loss of such a vital necessity to the existence of the country. Among those other efforts which should be made, the planting of Douglas fir should take a prominent place.

\section{GEOLOGY IN POST-WAR PLANNING}

\section{By Prof. P. G. H. BOSWELL, F.R.S.}

GROM the reply of the Secretary of State for War I to a question recently asked in the House of Commons, it seems that we have now arrived, in the fourth year of war, at the stage reached after the Gallipoli campaign of the War of 1914-18 ; for history is repeating itself in that water-divining in the Army is to be replaced by scientific methods of discovery (see Nature, January 30 , p. 118). A further, although belated, encouragement to geologists in their efforts to overcome public neglect of the science has just come from an American correspondent in the shape of news that the U.S. Geological Survey is actively co-operating in the preparation of maps for the North African campaign, and that geological staff officers are accompanying some of the U.S. task forces. If we do not relax our efforts it is 